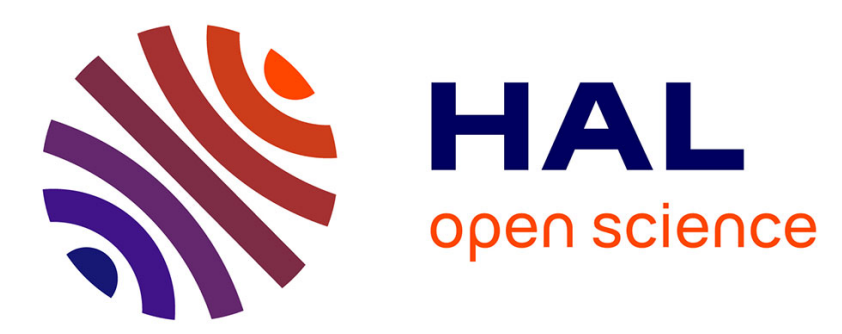

\title{
Increased brood viability and longer lifespan of honeybees selected for propolis production
}

Daniel Nicodemo, Euclides Malheiros, David de Jong, Regina Couto

\section{To cite this version:}

Daniel Nicodemo, Euclides Malheiros, David de Jong, Regina Couto. Increased brood viability and longer lifespan of honeybees selected for propolis production. Apidologie, 2014, 45 (2), pp.269-275. 10.1007/s13592-013-0249-y . hal-01234728

\section{HAL Id: hal-01234728 \\ https://hal.science/hal-01234728}

Submitted on 27 Nov 2015

HAL is a multi-disciplinary open access archive for the deposit and dissemination of scientific research documents, whether they are published or not. The documents may come from teaching and research institutions in France or abroad, or from public or private research centers.
L'archive ouverte pluridisciplinaire HAL, est destinée au dépôt et à la diffusion de documents scientifiques de niveau recherche, publiés ou non, émanant des établissements d'enseignement et de recherche français ou étrangers, des laboratoires publics ou privés. 


\title{
Increased brood viability and longer lifespan of honeybees selected for propolis production
}

\author{
Daniel Nicodemo ${ }^{1}$, Euclides Braga Malheiros ${ }^{2}$, David De Jong ${ }^{3}$, \\ Regina Helena Nogueira CouTo ${ }^{4}$ \\ ${ }^{1}$ Campus de Dracena, Curso de Zootecnia, Universidade Estadual Paulista, Dracena, SP, Brazil \\ ${ }^{2}$ Departamento de Ciências Exatas, Universidade Estadual Paulista, Jaboticabal, SP, Brazil \\ ${ }^{3}$ Departamento de Genética, Faculdade de Medicina, Universidade de São Paulo, Ribeirão Preto, SP, Brazil \\ ${ }^{4}$ Departamento de Zootecnia, Universidade Estadual Paulista, Jaboticabal, SP, Brazil
}

Received 7 June 2013 - Revised 4 September 2013 - Accepted 3 October 2013

\begin{abstract}
Propolis has been proposed to affect honeybee health. To test this hypothesis, we initially evaluated propolis production in 36 honeybee colonies. The three highest (HP) and three lowest propolis-producing (LP) colonies had mean yields of 16.0 and $0.64 \mathrm{~g}$, respectively. Queens and drones from these parental colonies were crossed by artificial insemination to produce five colonies each of the following crosses: $\mathrm{HP} q \times \mathrm{HP} \hat{\gamma}, \mathrm{HP}+\times$

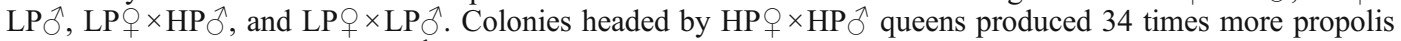
than those headed by LP + LP $\$$ queens and five times more than those from the other two crosses. Newly emerged bees were marked to measure longevity, and egg and brood counts were made to determine brood survival rates. The colonies with queens derived from crosses between high-propolis-producing colonies had significantly higher brood viability and greater worker bee longevity. We conclude that colonies that collect more propolis are healthier and have longer-living bees.
\end{abstract}

controlled mating / propolis / brood viability / longevity

\section{INTRODUCTION}

Propolis is a product of honeybee colonies that, because of its therapeutic properties, has been widely used in human medicine (Marcucci 1995; Sforcin and Bankova 2011). Because propolis is not normally stored in large quantities in the colony, as is honey, beekeepers induce its production to obtain quantities that permit its commercialization. Propolis productivity can vary from 300 up to $1,450 \mathrm{~g} / \mathrm{hive} / \mathrm{year}$, if production techniques are implemented (Prost-Jean 1985; Breyer 1995; Inoue et al. 2007). Manrique and Soares (2002) have

Corresponding author: D. De Jong,

ddjong@fmrp.usp.br

Manuscipt editor: Peter Rosenkranz reported that propolis production and honey production are positively correlated. It is also known that greater availability of food positively affects the longevity of bees (Kulincevic et al. 1982; Weiss 1984; Graham 1997).

To increase the production of bee products, it is necessary to understand the factors that influence yield. We know, for instance, that colony productivity is greatly affected by its health. Brood viability is also affected by colony size, which in turn affects the capacity of the bees to maintain optimal temperature and humidity conditions in the brood nest (Sakagami and Fukuda 1968; Garófalo 1977). Worker longevity is also affected by climatic conditions, availability of pollen and nectar, the adult bee population and brood area (Malone et al. 1995), infestation by Varroa 
destructor (De Jong and De Jong 1983), the race of the bees (Doull 1980), and royal jelly production capacity (Azevedo 1996).

The lifespan of honeybee workers is an important factor to be considered in beekeeping. There is a significant relationship between foraging behavior and mortality; bees that delay the transition to foraging live longer (Page and Peng 2001). However, other factors can be involved in honeybee lifespan, such as chronological aging, behavioral and physiological profiles, and extrinsic mortality (Rueppell et al. 2007).

The plasticity of the lifespan of honeybees is evident. European bee workers live approximately 6 weeks in the summer and up to 6 months in the winter. This indicates that environmental factors affect worker longevity (Seeley 1995; Remolina and Hughes 2008). Even old worker bees can display normal olfactory and tactile acquisition and discrimination, although they have a slightly impaired long-term olfactory memory (Behrends and Scheiner 2010).

Simone-Finstrom and Spivak (2010) reported that social immunity is a promising area of study in social insect biology. Among the behaviors controlled by colony needs, resin collection and production of propolis, which have antimicrobrial properties, reduce microbe levels in the honeybee colony and may help in disease resistance (Cremer and Sixt 2009; Simone et al. 2009). Considering that propolis has been considered to affect the health of honeybees, we investigated whether propolis production affects brood viability and worker lifespan.

\section{MATERIAL AND METHODS}

This study was conducted in the municipality of Jaboticabal, São Paulo State, Brazil. This area has a subtropical climate, with a mean annual temperature of $21{ }^{\circ} \mathrm{C}$ and a mean annual rainfall of $1,431 \mathrm{~mm}$. The region is characterized by a sugarcane monoculture.

After following the propolis production of 36 colonies of Africanized honeybees (Apis mellifera) for 2 months, we selected three good propolis producers (HP) and three poor producers (LP), to compose the group of parental hives. Queens and drones reared from these six parental colonies were crossed through artificial insemination to produce five colonies each of the following crosses,

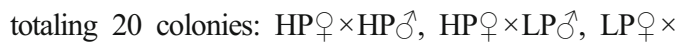

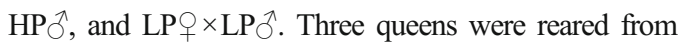
each parental colony. An additional (fourth) queen was reared from each of the two colonies that produced the most and the least amount of propolis. Each queen was inseminated with semen from six drones, three from one colony and three from another colony of the same propolis-producing category. These drones were always selected from colonies different from the colony used to rear the virgin queen that was being inseminated. All of the colonies were maintained in standard one deep Langstroth 10-frame hives.

After a period of 70 days from the introduction of the queens, it was considered that the workers had been completely replaced by descendants of the controlled matings, and data collection was initiated. Propolis production was determined by weighing the propolis deposited in the propolis collectors. These collectors were made of two flat frames of thin wood 3-mm thick and 20-mm wide, with the dimensions of a queen excluder frame, separated by wooden blocks $(2 \times 2 \times 2 \mathrm{~cm})$, two in each corner and one in the middle of each side (Figure 1). The propolis was harvested after 2 months in the parental colonies and after 1 month in the progeny colonies.

The 36 hives included in the selection process were fed with syrup (equal parts of water and sucrose - $w / w$ ), and manipulations were made, ensuring that all the colonies had similar conditions with respect to brood area, food (honey and pollen), and approximate number of bees. To determine the production and viability of brood, each queen was placed in a cage made with queen excluder material, containing an empty comb, placed in the center of the hive. After $24 \mathrm{~h}$, the comb was taken to the laboratory for egg counts. The frames were covered with a cloth moistened with warm water during transport. After the counts, the frames were reintroduced to their respective hives.

These combs were taken to the laboratory for counts of larvae on the fourth day and for counts of pupae on the 11th day. On the 19th day, the combs were stored in an incubator at $33{ }^{\circ} \mathrm{C}$ to allow counts of the emerging workers. In this way, it was possible to estimate losses occurring at each stage of the development and the number of adult bees born relative to the number of eggs laid by each queen. 


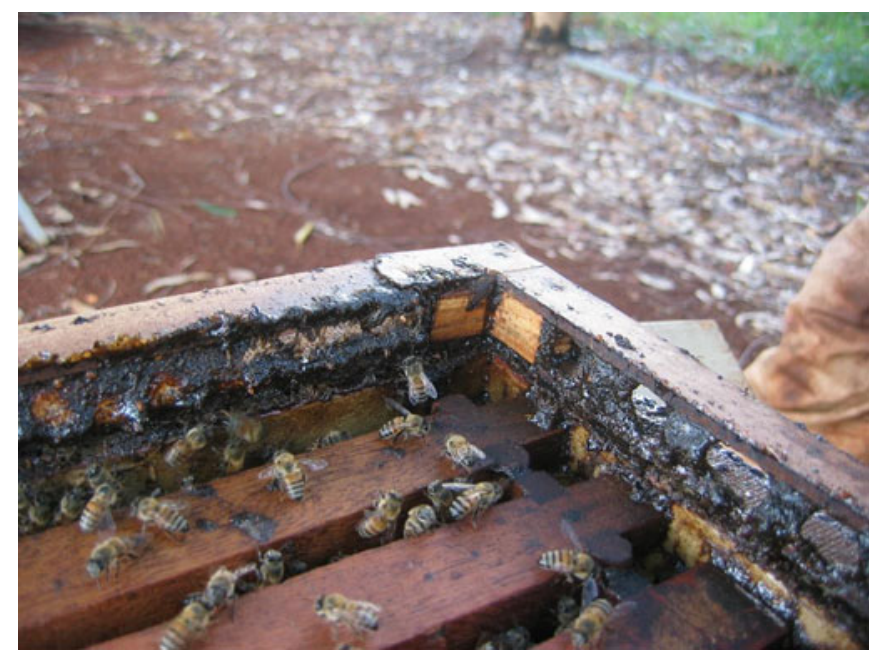

Figure 1. Detail of a propolis collecting frame placed between the cover (removed for this photo) and the hive body. Propolis is deposited in the 2-cm space between the wood slats.

To determine how propolis production affects worker lifespan, we used the parental colonies as hosts for newly emerged bees from the F1 colonies. These parental colonies were fed during the course of the study in order to maintain similar internal conditions in terms of amounts of food, brood, and adult bees, so that the principal difference between them was propolis production.

We removed a brood comb containing sealed brood about to emerge from each descendant hive. The combs were taken to the laboratory, placed in a screened cage, and stored in an incubator at $33{ }^{\circ} \mathrm{C}$, with a relative humidity between 70 and $80 \%$. As the adult workers emerged, we marked ten bees from each comb by gluing numbered disks (Opalithplättchen) of different colors to the thorax to allow future identification. Two hundred bees were thus marked ( 50 bees from each F1 group). Half of these (five from each F1 colony) were introduced into a parental HP colony and the other half into a parental LP colony. This procedure was repeated five times, so that longevity was measured for 1,000 bees. Two of each of the HP and LP parental colonies were used twice as host colonies, and the third colony of each parental type was used once. The marked bees were counted daily until the tenth day after observation of the last labeled worker, according to the method proposed by Terada et al. (1975).
To compare the four offspring groups in terms of propolis production and egg laying and egg viability, an analysis of variance was performed using a completely randomized design with five replicates. To compare the lifespan of bees from the descendant groups, we conducted a factorial analysis using two factors (environment and hive of origin). A comparison of means was performed using Tukey's test, and the data were processed with SAS software (1993).

\section{RESULTS}

In 2 months, the HP hives produced an average of $16.00 \pm 7.70 \mathrm{~g}$ of propolis, and the LP hives produced an average of $0.64 \pm 0.54 \mathrm{~g}$. The propolis production of the offspring colonies was also analyzed; we observed that the colonies headed by $\mathrm{HP} \propto \times \mathrm{HP} \hat{\bigcirc}$ queens produced an average of $22.43 \pm 12.97 \mathrm{~g}$ of propolis in 1 month. The mean propolis production of these colonies was greater $(P<0.05)$ than that of colonies headed by $\mathrm{HP} q \times$ $\mathrm{LP}^{\lambda}(4.28 \pm 2.52 \mathrm{~g}), \mathrm{LP}+\times \mathrm{HP}^{\lambda}(3.99 \pm 5.16 \mathrm{~g})$, or

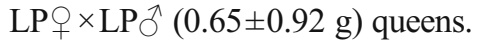

The number of eggs laid in a period of $24 \mathrm{~h}$ was higher for the $\mathrm{HP} \propto \times \mathrm{LP} \widehat{\bigcirc}$ queens, followed by $\mathrm{LP} q \times \mathrm{HP}^{\hat{\sigma}}, \mathrm{LP} q \times \mathrm{LP}^{\hat{\sigma}}$, and $\mathrm{HP} q \times \mathrm{HP}^{\hat{O}}$. The egg production was $10.5 \%$ higher for the 
$\mathrm{HP} q \times \operatorname{LP} \hat{o}$ queens than for the $\mathrm{HP} q \times \operatorname{HP} \hat{O}$ or $\mathrm{LP} O \times$ LP $\widehat{O}$ queens (Table I).

Between the egg and larval phases, the losses were greater in $\mathrm{LP}+\times \mathrm{LP}^{-}$colonies $(2.92 \%)$ and smaller in $\mathrm{HP}+\times \mathrm{HP} \widehat{O}$ colonies $(1.76 \%)$; this is a $71 \%$ greater loss in colonies with low propolis production. During the interval from larva to pupa, the losses were also greater in the $\mathrm{LP} q \times \operatorname{LP} \widehat{O}(1.45 \%)$ compared to the $\mathrm{HP} q \times$ HP $\widehat{\partial}$ colonies $(0.97 \%)$. The low-propolisproducing colonies had a nearly $50 \%$ greater loss of brood during the interval from larva to pupa. During the pupal phase, the losses were $0.63 \%$ for $\mathrm{LP}+\times \mathrm{LP}{ }^{-1}$ colonies compared to $0.36 \%$ for $\mathrm{HP}+\times \mathrm{HP} \hat{O}$ colonies. Total brood mortality was approximately $3 \%$ in $\mathrm{HP}+\times \mathrm{HP}{ }^{\wedge}$ colonies and $5 \%$ in $\mathrm{LP}+\times \mathrm{LP} \hat{\gamma}$ colonies. Brood mortality was intermediate (about $4 \%$ ) in the hybrid cross of low propolis production crossed with high propolis production.

Adult bee longevity was generally greater for bees with higher-propolis-producing potential (Table II), though the differences were not significant. Independent of their genetic background, bees maintained in high-propolisproducing colonies lived significantly longer than those maintained in low-propolis-producing colonies (Table II).

\section{DISCUSSION}

The small amounts of propolis obtained, even in the most productive hives, can be explained by the poor bee pastures in the region of Jaboticabal, which is characterized by a sugarcane monoculture. It is known that when the flora provides large amounts of raw material, propolis production can be much higher (Inoue et al. 2007). We did not make qualitative analyses of the propolis that was collected in this experiment. Differences in the chemical composition of propolis are common among samples collected from different locations and even from hives in the same apiary (Bankova et al. 2002). Brazilian propolis, especially green propolis, has a wide spectrum of active ingredients, some of which are present in very small quantities but have a high degree of biological activity. These specific properties are not found in other types of propolis, including propolis produced in Europe from resin collected by the bees from Populus spp. (Couto and Couto 2006; Righi et al. 2013).

The superior queens (in terms of egg production) were those obtained from crossing bees from highand low-propolis-producing colonies. These queens produced from 6.3 to $10.5 \%$ more eggs than did those originating from only one selected line. However, during brood development, the mortality differed between the groups, indicating that the viability of the offspring was related to the ability to produce propolis.

The greatest losses were observed from the egg stage to the initial larval stages in all propolis production groups. Generally, the losses were smaller as the time to the adult bees' emergence approached. The highest and lowest loss rates occurred in the colonies with queens selected for low and high production of propolis, respectively.

Table I. Mean \pm standard deviation of the number of eggs, larvae, pupae and adult bees produced during $24 \mathrm{~h}$, and mortality during the brood stage (interval from egg to adult), in colonies that were descendants of colonies selected for high (HP) and low production of propolis (LP) (five colonies in each group).

\begin{tabular}{|c|c|c|c|c|c|}
\hline \multirow[t]{2}{*}{ Group } & \multicolumn{4}{|l|}{ Stage } & \multirow[t]{2}{*}{ Mortality (\%) } \\
\hline & Eggs & Larvae & Pupae & Adults & \\
\hline $\mathrm{HP} q \times \mathrm{HP}^{\hat{O}}$ & $398.0 \pm 10.4 b$ & $391.0 \pm 10.8 b$ & $387.2 \pm 10.7 b$ & $385.8 \pm 10.6 b$ & 3.1 \\
\hline $\mathrm{LP}+\times \mathrm{HP}^{\lambda}$ & $439.6 \pm 26.1 \mathrm{a}$ & $429.4 \pm 25.1 \mathrm{a}$ & $424.4 \pm 24.7 \mathrm{a}$ & $422.4 \pm 23.5 \mathrm{a}$ & 3.9 \\
\hline $\mathrm{HP} \propto \times \mathrm{LP}{ }^{\lambda}$ & $423.0 \pm 10.8 \mathrm{ab}$ & $412.8 \pm 10.6 \mathrm{ab}$ & $407.6 \pm 10.9 \mathrm{ab}$ & $405.6 \pm 12.2 \mathrm{ab}$ & 4.1 \\
\hline $\mathrm{LP}_{+} \times \mathrm{LP}^{\hat{O}}$ & $397.8 \pm 13.8 b$ & $386.2 \pm 16.0 \mathrm{~b}$ & $380.6 \pm 17.9 b$ & $378.2 \pm 15.6 \mathrm{~b}$ & 4.9 \\
\hline
\end{tabular}

Mean values followed by the same letter do not differ significantly $(P>0.05)$, according to Tukey's test 
Table II. Lifespan in days (mean \pm standard deviation) of worker bees from the four types of $\mathrm{F} 1$ colonies maintained in colonies with high (HP) and low (LP) propolis production; 250 bees of each type were analyzed.

\begin{tabular}{lll}
\hline \multirow{2}{*}{ Type of bee } & \multicolumn{2}{l}{ Host colony } \\
\cline { 2 - 3 } & HP & LP \\
\hline $\mathrm{HP}_{+} \times \mathrm{HP}^{\lambda}$ & $30.3 \pm 0.9$ & $28.4 \pm 1.1$ \\
$\mathrm{LP}_{+} \times \mathrm{HP}^{-}$ & $30.1 \pm 1.0$ & $27.7 \pm 1.4$ \\
$\mathrm{HP}_{+} \times \mathrm{LP}^{\hat{O}}$ & $29.3 \pm 1.1$ & $27.4 \pm 0.9$ \\
$\mathrm{LP}_{+} \times \mathrm{LP}^{\lambda}$ & $27.9 \pm 0.4$ & $26.8 \pm 0.8$ \\
Overall mean & $29.4 \pm 0.8 \mathrm{a}$ & $27.6 \pm 0.9 \mathrm{~b}$ \\
\hline
\end{tabular}

Means followed by different letters differ significantly $(P<0.05)$, according to Tukey's test

Wu et al. (2011) studied the effects of pesticide exposure from contaminated brood combs on the development of European worker bees and reported brood losses of $26 \%$ for the control group and $33 \%$ for the treatment group. In our experiments, the greatest losses did not exceed $5 \%$, which could be explained by the lower susceptibility to diseases of Africanized honeybees compared with other bee races (Gramacho and Gonçalves 2009). We observed that as the ability to produce propolis increased, the colonies lost fewer individuals during brood development.

In an in vitro study, Bastos et al. (2008) found that propolis extracts from various regions of Brazil caused significant inhibition of growth of the honeybee pathogen Paenibacillus larvae. This emphasizes the importance of propolis for colony health, providing a possible alternative to the use of antibiotics. SimoneFinstrom and Spivak (2012) demonstrated that "social immunity" is a strategy used by honeybees when they collect resins. After a challenge with a fungal parasite (Ascosphaera apis, which causes chalkbrood), the honeybees increased resin foraging rates, using more individuals for this activity; this was understood as selfmedication. In this case, the adult bees increased propolis collection due to infection of the brood with the fungus. Self-medication is meant in the sense that the brood that is being protected is part of the same eusocial superorganism as the nurse bees.

Considering the type of colony (HP or LP) as a source of variation, we observed that adult worker lifespan was $6.6 \%$ greater when there was more propolis in a hive. A larger amount of propolis in the hive apparently contributed to increasing the longevity of the honeybees. We can consider that there is a positive relationship between these two factors. Hives with more propolis could also improve honey production since longer-living bees can forage for a longer period, resulting in increased colony productivity (Doull 1980).

Mlagan and Sulimanovic (1982) found that one-frame colonies treated with alcohol and aqueous extracts of propolis had fewer diseased larvae compared with control colonies. Similar findings were reported by Antúnez et al. (2008), who added propolis to sugar syrup and found reduced numbers of $P$. larvae spores in the treated colonies.

Honeybees exposed to aqueous extracts of propolis have been found to have altered expression of immune system genes from third instar larvae to the adult phase. Propolis in the colony decreases investment in immune functions in 7-day-old bees, demonstrating that the hive environment can affect immune gene expression (Simone et al. 2009).

Colonies with high propolis production had a lower loss of brood rate compared to colonies with low propolis production. The larger amounts of propolis in the colonies also appeared to have a positive influence on the longevity of the worker bees. However, these observations do not necessarily prove a causal relationship, as other unknown factors could increase propolis production along with honeybee lifespan and brood survival.

\section{ACKNOWLEDGMENTS}

The authors thank CAPES (Coordenação de Aperfeiçoamento de Pessoal de Nível Superior) for a scholarship for D.N. and CNPq (Conselho Nacional de Desenvolvimento Científico e Tecnológico) for financial assistance. Anonymous reviewers made helpful comments that improved the manuscript. 
Viabilité du couvain et durée de vie accrues chez des abeilles sélectionnées pour leur production de propolis

\author{
Reproduction contrôlée / propolis / viabilité du \\ couvain / longévité
}

Höhere Brutüberlebensraten und längere Lebensdauer bei Honigbienen, die auf höhere Propolisproduktion selektiert wurden

\section{Kontrollierte Paarung / Propolis / Brutüberlebensraten / Lebensdauer}

\section{REFERENCES}

Antúnez, K., Harriet, J., Gende, L., Maggi, M., Eguaras, M., Zunino, P. (2008) Efficacy of natural propolis extract in the control of American foulbrood. Vet. Microbiol. 131, 324-331

Azevedo A.L.G. (1996) Estudo de parâmetros relacionados com a produção de geléia real em colméias de Apis mellifera mais e menos produtivas. Doctoral thesis, Faculdade de Ciências Agrárias e Veterinárias, Universidade Estadual Paulista, Jaboticabal, SP, Brazil

Bankova, V., Popova, M., Bogdanov, S., Sabatini, A.G. (2002) Chemical composition of European propolis: expected and unexpected results. Z Naturforsch 57(5-6), 530-533

Bastos, E.M.A.F., Simone, M., Jorge, D.M., Soares, A.E.E., Spivak, M. (2008) In vitro study of the antimicrobial activity of Brazilian propolis against Paenibacillus larvae. J. Invertebr. Pathol. 97(3), 273-281

Behrends, A., Scheiner, R. (2010) Learning at old age: a study on winter bees. Front. Behav. Neurosci. . doi:10.3389/fnbeh.2010.00015

Breyer, H.F.E. (1995) Aspectos de produção, coleta, limpeza, classificação e acondicionamento de própolis bruta de abelhas Apis mellifera L, p. 143. Anais do $7^{\circ}$ Simpósio Estadual de Apicultura do Paraná, Prudentópolis

Couto, R.H.N., Couto, L.A. (2006) Apicultura: manejo e produtos. Funep, Jaboticabal

Cremer, S., Sixt, M. (2009) Analogies in the evolution of individual and social immunity. Philos. Trans. R. Soc. Lond. B. Biol. Sci. 364, 129-142

De Jong, D., De Jong, P.H. (1983) Longevity of Africanized honey bees (Hymenoptera: Apidae) infested by Varroa jacobsoni (Parasitiformes: Varroaidae). J. Econ. Entomol. 76(4), 766-768

Doull, K.M. (1980) Relationships between consumption of a pollen supplement, honey production and brood rearing in colonies of honeybees Apis mellifera $\mathrm{L}$. Apidologie 14(4), 362-365

Garófalo, A.C. (1977) Brood viability in normal colonies of Apis mellifera. J. Apic. Res. 16(1), 3-13

Graham, J.M. (1997) The hive and the honey bee. Dadant \& Sons, Hamilton

Gramacho, K.P., Gonçalves, L.S. (2009) Comparative study of the hygienic behavior of Carniolan and Africanized honey bees directed towards grouped versus isolated dead brood cells. Genet. Mol. Res. 8(2), 744-750

Inoue, H.T., Sousa, E.A., Orsi, R.O., Funari, S.R.C., Carelli Barreto, L.M.R., Da Silva, D.A.P. (2007) Produção de própolis por diferentes métodos de coleta. Arch. Latinoam. Prod. Anim. 15(2), 6569

Kulincevic, J.M., Rothenbulher, W.C., Rinderer, T.E. (1982) Disappearing disease. Part 1-Effects of certain protein sources given to honey bee colonies in Florida. Am. Bee. J 122(3), 198-191

Malone, L.A., Giacon, H.A., Newton, M.R. (1995) Comparison of the responses of some New Zealand and Australian honey bees (Apis mellifera L.) to Nosema apis Z. Apidologie 26(6), 495-502

Manrique, A.J., Soares, A.E.E. (2002) Início de um programa de seleção de abelhas Africanizadas para a melhoria na produção de própolis e seu efeito na produção de mel. Interciencia 27(6), 312-316

Marcucci, M.C. (1995) Propolis: chemical composition, biological properties and therapeutic activity. Apidologie 26(2), 83-99

Mlagan, V., Sulimanovic, D. (1982) Action of propolis solutions on Bacillus larvae. Apiacta 17, 16-20

Page, R.E., Peng, Y.S.C. (2001) Aging and development in social insects with emphasis on the honey bee. Apis mellifera L. Exp. Gerontol. 36(4-6), 695-711

Prost-Jean, P. (1985) Apicultura, 2nd edn. Ediciones Mundi-Prensa, Madrid

Remolina, S.C., Hughes, K.A. (2008) Evolution and mechanisms of long life and high fertility in queen honey bees. Age 30(2-3), 177-185

Righi A.A., Negri G., Salatino A. (2013) Comparative Chemistry of Propolis from Eight Brazilian Localities. Evid.-Based Compl. Alt. Article ID 267878; 2013:1-14. doi:10.1155/2013/267878

Rueppell, O., Bachelier, C., Fondrik, M.K., Page Jr., R.E. (2007) Regulation of life history determines lifespan of worker honey bees (Apis mellifera L.). Exp Gerontol 42(10), 1020-1032

Sakagami, S.F., Fukuda, H. (1968) Worker brood survival in honey bees. Res. Pop. Ecol. 10(1), 31-39

SAS Institute- Statistical analysis systems (1993) User's guide: Stat. Version 6, 12. 4. ed. Cary.

Seeley, T.D. (1995) The Wisdom of the Hive. Harvard University Press, Cambridge 
Sforcin, J.M., Bankova, V. (2011) Propolis: is there a potential for the development of new drugs? J. Ethnopharmacol. 133(2), 253-260

Simone, M., Evans, J.D., Spivak, M. (2009) Resin collection and social immunity in honey bees. Evolution 63(11), 3016-3022

Simone-Finstrom, M.D., Spivak, M. (2010) Propolis and bee health: the natural history and significance of resin use by honey bees. Apidologie 41(3), 295-311

Simone-Finstrom, M.D., Spivak, M. (2012) Increased resin collection after parasite challenge: a case of selfmedication in honey bees? PLoS ONE 7, e34601
Terada, Y., Garófalo, C.A., Sakagami, S.F. (1975) Agesurvival curves for workers of two eusocial bees (Apis mellifera and Plebeia droryana) in a subtropical climate, with notes on worker polyethism in $P$. droryana. J. Apic. Res 14(3/4), 161-170

Weiss, K. (1984) Regulierung des proteinhaushaltes im bienenvolk (Apis mellifica L.) durch brutkannibalismus. Apidologie 15(3), 339-354

Wu, J.Y., Anelli, C.M., Sheppard, W.S. (2011) Sub-lethal effects of pesticide residues in brood comb on worker honey bee (Apis mellifera) development and longevity. PLoS ONE 6, e14720 